\title{
Mortality of workers manufacturing friction materials using asbestos
}

\author{
G BERRY* AND M L NEWHOUSE \\ From the MRC Pneumoconiosis Unit, Llandough Hospital, Penarth, S Glamorgan, and TUC Centenary \\ Institute of Occupational Health, London School of Hygiene and Tropical Medicine, London, UK
}

ABSTRACT A mortality (1942-80) study was carried out on 13460 workers of a factory producing friction materials. The only type of asbestos used was chrysotile, except during two well-defined periods before 1945 when crocidolite was used, and over $99 \%$ of the population was traced. Compared with national death rates there were no detectable excesses of deaths due to lung cancer. gastrointestinal cancer, or other cancers; 11 deaths were due to pleural mesothelioma. A casecontrol study was carried out on deaths due to mesothelioma; this showed that eight workers had been exposed to crocidolite and another was possibly exposed intermittently to crocidolite. The other two had been employed for most of their working lives outside the factory, and their mesotheliomas could not be definitely attributed to exposure to chrysotile. Limiting the study to cases and controls who had exposure to 5 fibres $/ \mathrm{ml}$ of chrysotile asbestos it was found that five of the six cases compared with two of the 10 controls had also been exposed to crocidolite. The probability (1:36) of this occurring were there no association with crocidolite is most unlikely. A case-control study was also carried out on deaths due to lung cancer and gastrointestinal cancer to investigate the dose-response relationships between these tumours and exposure to chrysotile. Measured and estimated fibre concentrations were available for the different jobs over the period of the study. No dose-response relationships were observed, but the exposures were low with only $5 \%$ of men accumulating 100 fibre-years $/ \mathrm{ml}$. The experience at this factory over a 40 -year period showed that chrysotile asbestos was processed with no detectable excess mortality.

We describe the mortality of workers in a factory producing friction materials where, except for two periods, chrysotile was the only type of asbestos used. The factory was founded in 1898 and has continued since then to manufacture brake blocks, brake and clutch linings, and other friction materials such as stair-treads. Woven asbestos belting was introduced experimentally in 1910 and by 1920 had become an essential constituent of the process. The woven asbestos was bought in from another source, and at no time did asbestos textile operations take place in the factory. Non-woven asbestos fibre was introduced after a method of making brake blocks using chrysotile fibre and resin cast in a die was patented. The proportion of products using non-woven fibre

*Present address: Commonwealth Institute of Health, University of Sydney. Sydney. New South Wales 2006. Australia.

Received 23 June 1982

Accepted 3 August 1982 increased to about one-sixth of total production by 1940); the output of this type of product continued to expand and in 1960) the operations with woven asbestos were transferred to another factory.

Chrysotile was the most suitable type of asbestos and has been used almost exclusively. The two exceptions were during 1929-33 and 1939-44 when crocidolite asbestos fibre was specified in a contract for railway blocks. In both these periods the blocks were produced in a well-defined area of one of the workshops, and only a minority of the work-force was concerned. Very small quantities of crocidolite have also been used from time to time in the experimental workshop.

The main processes carried out in the factory have been the coating of fibre in resin. forming to the required shape and machining.

The objectives of the mortality study were:

(1) To establish the effects of exposure to asbestos in this factory, 
(2) To test for an association between type of asbestos and mesothelioma, and

(3) To examine the data for a dose-response relationship between exposure to chrysotile and cancer of the lung or gastrointestinal tract.

Results relevant to the first two objectives were given previously' but are now supplemented by new data. Data relevant to the third objective are given in full.

\section{Environmental conditions}

There were major improvements in environmental conditions over the years, but regular measurements of airborne dust levels were only introduced in 1967 using the membrane filter method; personal sampling began in 1968. Fibre concentrations in earlier years have been estimated by reproducing earlier working conditions using detailed knowledge of when processes were changed and exhaust ventilation introduced. ${ }^{2}$ Up to 1931 most of the operations concerned exposures higher than 20 fibres $/ \mathrm{ml}(\mathrm{f} / \mathrm{ml})$ (table 1). After this the Asbestos Regulations ${ }^{3}$ produced a major improvement, and most of the jobs had exposures of under $5 \mathrm{f} / \mathrm{ml}$; the exceptions were grinding (5-10 f/ml) and fibre preparation (10-20 f/ $\mathrm{ml}$ ). There was little change between 1932 and 1950 but then came a period of gradual improvement, and all exposures were reduced to under $5 \mathrm{f} / \mathrm{ml}$. Efforts to comply with the regulations of $1969^{4}$ resulted in a further improvement, with all exposures reduced to under $2 \mathrm{f} / \mathrm{ml}$.

\section{Population and methods}

In 1941 the present personnel filing system of all employees was instituted. Identification details were kept together with the dates of employment at the factory. The actual job was not recorded explicitly but the "cost-centre" of the work was coded. These codes changed frequently and could be interpreted only by personnel staff. As this was too laborious to carry out for all 13000 employees job histories were extracted only for groups of special interest.

The population included in the study consisted of all those employed in 1941 or at any time later, a total of 13460 subjects, of whom about two-thirds were

Table 1 Mean concentration of asbestos in air $(\mathrm{f} / \mathrm{ml})$

\begin{tabular}{lllll}
\hline Period & $\begin{array}{l}\text { Officel } \\
\text { laboratory }\end{array}$ & $\begin{array}{l}\text { Storagel } \\
\text { distribution }\end{array}$ & Grinding & Forming \\
\hline Pre-1931 & $10-20$ & $>20$ & $>20$ & $>20$ \\
$1932-50$ & $<0 \cdot 5$ & $2-5$ & $5-10$ & $2-5$ \\
$1951-69$ & $<0 \cdot 5$ & $2-5$ & $2-5$ & $1-2$ \\
$1970-79$ & $<0.5$ & $0.5-1$ & $0.5-1$ & $0.5-1$ \\
\hline
\end{tabular}

Table 2 Year started work in factory*

\begin{tabular}{lrrrrr}
\hline Period & \multicolumn{2}{c}{ Men } & & \multicolumn{2}{c}{ Women } \\
\cline { 2 - 3 } \cline { 5 - 6 } & \multicolumn{1}{c}{ No } & \multicolumn{2}{c}{$\%$} & & \multicolumn{2}{c}{ No } & $\%$ \\
\hline Pre-1940 & 500 & $5 \cdot 5$ & & 266 & $6 \cdot 1$ \\
$1941-50$ & 2499 & $27 \cdot 5$ & & 1383 & $31 \cdot 9$ \\
$1951-60$ & 3068 & $33 \cdot 7$ & & 1269 & $29 \cdot 3$ \\
$1961-70$ & 2060 & $22 \cdot 7$ & & 976 & $22 \cdot 5$ \\
$1971-$ & 960 & $10 \cdot 6$ & & 444 & $10 \cdot 2$ \\
Total & 9087 & $100 \cdot 0$ & & 4338 & $100 \cdot 0$ \\
\hline
\end{tabular}

* In this table, and in tables 3-5, 35 subjects with incomplete identity information have been omitted.

men. The size of the work-force was about 1000 in 1942 but had increased to 2000 by the late 1940 s and remained above this level up to 1977 , when the study started. Except during and immediately after the war, over three-quarters of the work-force were men. Table 2 shows the distribution of year of starting work at the factory. Those starting before 1941 do not form the complete group of workers in the early years, since those who had left earlier would not have been included in the personnel files; they included some men and women who had started at the factory before 1920. Over two-thirds of the population had started by 1960 and so would have been followed up for at least 20 years since their first exposure to asbestos. Tables 3 and 4 give the distributions of year of birth and age at start of work at the factory. On average, the women were born slightly later than the men and started work younger. Most men and women had just one continuous spell of work at the factory but some $(16 \%)$ had one or more breaks in their employment; table 5 shows the distribution of duration of service. Almost one-third of men and women left after under a year's service, but $27 \%$ of the men and $14 \%$ of the women stayed for 10 years or more.

Identification details were extracted from the personnel files and used as a basis for tracing by the Office of Population Censuses and Surveys (OPCS) and the Department of Health and Social Security (DHSS). A high trace rate was obtained (table 6). For those who had died, a copy of the death entry was obtained and the cause of death coded using the 8th

Table 3 Year of birth

\begin{tabular}{|c|c|c|c|c|}
\hline \multirow[t]{2}{*}{ Period } & \multicolumn{2}{|l|}{ Men } & \multicolumn{2}{|c|}{ Women } \\
\hline & No & $\%$ & No & $\%$ \\
\hline $\begin{array}{l}\text { Pre-1899 } \\
1900-9 \\
1910-9 \\
1920-9 \\
1930-9 \\
1940-9 \\
1950-9 \\
1960-\end{array}$ & $\begin{array}{r}569 \\
973 \\
1466 \\
2027 \\
1905 \\
1467 \\
652 \\
28\end{array}$ & $\begin{array}{r}6 \cdot 3 \\
10 \cdot 7 \\
16 \cdot 1 \\
22 \cdot 3 \\
21 \cdot 0 \\
16 \cdot 1 \\
7 \cdot 2 \\
0.3\end{array}$ & $\begin{array}{r}155 \\
313 \\
495 \\
973 \\
1011 \\
909 \\
437 \\
45\end{array}$ & $\begin{array}{r}3 \cdot 6 \\
7 \cdot 2 \\
11 \cdot 4 \\
22 \cdot 4 \\
23 \cdot 3 \\
21 \cdot 0 \\
10 \cdot 1 \\
1 \cdot 0\end{array}$ \\
\hline
\end{tabular}


Table 4 Age at start of employment in factory

\begin{tabular}{|c|c|c|c|c|}
\hline \multirow[t]{2}{*}{ Age } & \multicolumn{2}{|l|}{ Men } & \multicolumn{2}{|c|}{ Women } \\
\hline & No & $\%$ & No & $\%$ \\
\hline $\begin{array}{l}\text { Pre-24 } \\
25-34 \\
35-44 \\
45-54 \\
55-64\end{array}$ & $\begin{array}{r}3905 \\
2438 \\
1552 \\
846 \\
346\end{array}$ & $\begin{array}{r}43 \cdot 0 \\
26 \cdot 8 \\
17 \cdot 1 \\
9 \cdot 3 \\
3 \cdot 8\end{array}$ & $\begin{array}{r}2988 \\
538 \\
482 \\
273 \\
57\end{array}$ & $\begin{array}{r}68 \cdot 9 \\
12 \cdot 4 \\
11 \cdot 1 \\
6 \cdot 3 \\
1 \cdot 3\end{array}$ \\
\hline
\end{tabular}

Table 5 Total duration of service (years)

\begin{tabular}{|c|c|c|c|c|}
\hline \multirow[t]{2}{*}{ Years } & \multicolumn{2}{|l|}{ Men } & \multicolumn{2}{|c|}{ Women } \\
\hline & No & $\%$ & No & $\%$ \\
\hline $\begin{array}{l}<1 \\
1-1.9 \\
2-4 \cdot 9 \\
5-9.9 \\
10-19 \cdot 9 \\
20-29 \cdot 9 \\
\geqslant 30\end{array}$ & $\begin{array}{r}2863 \\
1114 \\
1512 \\
1114 \\
1156 \\
821 \\
507\end{array}$ & $\begin{array}{r}31 \cdot 5 \\
12 \cdot 3 \\
16 \cdot 6 \\
12 \cdot 3 \\
12 \cdot 7 \\
9 \cdot 0 \\
5 \cdot 6\end{array}$ & $\begin{array}{r}1369 \\
621 \\
1038 \\
683 \\
430 \\
100 \\
97\end{array}$ & $\begin{array}{r}31 \cdot 6 \\
14 \cdot 3 \\
23 \cdot 9 \\
15 \cdot 7 \\
9 \cdot 9 \\
2 \cdot 3 \\
.2 \cdot 2\end{array}$ \\
\hline
\end{tabular}

revision of the International Classification of Diseases. ${ }^{5}$ Three analyses of mortality have been carried out corresponding to the three objectives of the study.

\section{Results}

OVERALL MORTALITY

The observed mortality was compared with that expected, based on sex-, age-, and period-specific death rates for England and Wales, using the subjectyears method. ${ }^{6}$ Attention was restricted to the period following 10 years after first employment in the factory, and follow-up was to the end of 1979. In addition to mortality from all causes, the separate causes of death considered were cancer of lung and pleura (ICD 162-163), cancer of the gastrointestinal tract (ICD 150-159), and all other cancers (ICD 140$149,160-161,170-207)$. Table 7 shows the total mortality. Apart from 10 pleural mesotheliomas there was no sign of any excess mortality. When the subjects were divided into groups according to duration of exposure there was still no sign of excess mortality nor of any trend in mortality with duration
Table 6 Trace status

\begin{tabular}{lrrrrr}
\hline Status & \multicolumn{2}{c}{ Men } & & \multicolumn{2}{c}{ Women } \\
\cline { 2 - 3 } \cline { 5 - 6 } & \multicolumn{1}{c}{ No } & \multicolumn{1}{c}{$\%$} & & \multicolumn{1}{c}{ No } & $\%$ \\
\hline Alive & 7017 & $77 \cdot 0$ & & 3833 & $88 \cdot 2$ \\
Dead & 1787 & $19 \cdot 6$ & & 386 & $8 \cdot 9$ \\
Emigrated & 254 & $2 \cdot 8$ & & 94 & $2 \cdot 2$ \\
Untraced & 55 & $0 \cdot 6$ & & 34 & $0 \cdot 8$ \\
Total & 9113 & $100 \cdot 0$ & & 4347 & $100 \cdot 0$ \\
\hline
\end{tabular}

of employment. ${ }^{1}$ Dividing the subjects according to the period of first employment again showed no excess mortality apart from the pleural mesotheliomas. This applied even to those with 30 years' follow-up who were first employed before 1950, when dust levels were high (table 1).

Among deaths from other cancers, there were two in men due to cancer of the larynx (expectation 3.6). Eight of the women died of cancer of the ovary (expectation $8 \cdot 1$ ) and 22 of cancer of the breast (expectation 24:4).

The mortality experience of workers who completed 10 years' service is shown in table 8. Except for deaths from the mesothelial tumours there was no excess in this group, even 10 years after completing 10 years' service. A similar result was obtained when restricting attention to those who had completed 20 years' exposure. ${ }^{1}$

Since the mortality analysis was carried out, another 187 deaths have been notified occurring in the 18 months starting 1 January 1980 . Only one of 40 deaths in women and 12 of 147 in men were due to lung cancer. One of the men certified as dying of a pleural mesothelioma was 50 and had worked at the factory for two weeks in 1960 (when aged 29) as a grinder exposed to chrysotile asbestos. His main occupation was a fitter mechanic, and he is not known to have had any other exposure to asbestos. There was no postmortem examination, but examination of histological slides obtained from biopsy material before death confirmed the diagnosis.

TYPE OF ASBESTOS AND MESOTHELIOMA

The 10 subjects who died of mesothelioma in the

Table 7 Observed and expected mortality after 10 years from first exposure. (Number of pleural mesotheliomas included in parentheses)

\begin{tabular}{|c|c|c|c|c|}
\hline \multirow[t]{3}{*}{ Cause of death } & \multicolumn{4}{|c|}{ No/subject-years } \\
\hline & \multicolumn{2}{|c|}{$\begin{array}{l}\text { Men } \\
7474 / 104193\end{array}$} & \multicolumn{2}{|c|}{$\begin{array}{l}\text { Women } \\
3708 / 58816\end{array}$} \\
\hline & Obs & $\operatorname{Exp}$ & Obs & $\operatorname{Exp}$ \\
\hline $\begin{array}{l}\text { All causes } \\
\text { Lung and pleural cancer } \\
\text { Gastrointestinal cancer } \\
\text { Other cancers } \\
\text { Other causes }\end{array}$ & $\begin{array}{c}1339 \\
151(8) \\
103 \\
77 \\
1008\end{array}$ & $\begin{array}{r}1361 \cdot 8 \\
139 \cdot 5 \\
107 \cdot 2 \\
87 \cdot 7 \\
1027 \cdot 4 \\
\end{array}$ & $\begin{array}{l}299 \\
8(2) \\
29 \\
51 \\
211\end{array}$ & $\begin{array}{r}328 \cdot 0 \\
11 \cdot 3 \\
27 \cdot 4 \\
60 \cdot 0 \\
229 \cdot 3\end{array}$ \\
\hline
\end{tabular}


Table 8 Observed and expected mortality after completing 10 years' employment

\begin{tabular}{|c|c|c|c|c|c|c|c|c|}
\hline \multirow{4}{*}{$\begin{array}{l}\text { Follow-up after } 10 \\
\text { years' exposure (years) } \\
\text { No/subject-years } \\
\text { Cause of death }\end{array}$} & \multicolumn{4}{|l|}{ Men } & \multicolumn{4}{|c|}{ Women } \\
\hline & \multicolumn{2}{|l|}{$0-10$} & \multicolumn{2}{|l|}{$>10$} & \multicolumn{2}{|c|}{$0-10$} & \multicolumn{2}{|l|}{$>10$} \\
\hline & \multicolumn{2}{|c|}{$2484 / 21860$} & \multicolumn{2}{|c|}{$1808 / 19025$} & \multicolumn{2}{|c|}{$627 / 5578$} & \multicolumn{2}{|c|}{$457 / 6377$} \\
\hline & Obs & Exp & Obs & $\operatorname{Exp}$ & Obs & $\operatorname{Exp}$ & Obs & $\operatorname{Exp}$ \\
\hline $\begin{array}{l}\text { All causes } \\
\text { Lung and pleural cancer } \\
\text { Gastrointestinal cancer } \\
\text { Other cancers } \\
\text { Other causes }\end{array}$ & $\begin{array}{r}185 \\
23 \\
23 \\
7 \\
132\end{array}$ & $\begin{array}{r}195 \cdot 7 \\
21 \cdot 3 \\
16 \cdot 3 \\
12 \cdot 6 \\
145 \cdot 5\end{array}$ & $\begin{array}{r}432 \\
58(7) \\
25 \\
21 \\
328\end{array}$ & $\begin{array}{r}450 \cdot 8 \\
47 \cdot 4 \\
35 \cdot 8 \\
28 \cdot 2 \\
339 \cdot 4\end{array}$ & $\begin{array}{r}14 \\
0 \\
0 \\
3 \\
11\end{array}$ & $\begin{array}{r}21 \cdot 3 \\
0 \cdot 7 \\
1 \cdot 8 \\
4 \cdot 5 \\
14 \cdot 3\end{array}$ & $\begin{array}{l}76 \\
2(1) \\
8 \\
14 \\
52\end{array}$ & $\begin{array}{r}66 \cdot 5 \\
2 \cdot 2 \\
5 \cdot 7 \\
10 \cdot 7 \\
47 \cdot 9\end{array}$ \\
\hline
\end{tabular}

main mortality study were looked at in more detail in a case-control study using the method of Liddell $\mathrm{et} \mathrm{al} .^{7}$ Four matched controls were chosen for each mesothelioma, where matching was for: (1) sex, (2) year started work in factory ( \pm one year), (3) year of birth ( \pm four years), (4) survival up to time of death of mesothelioma, and (5) employed at factory during crocidolite period for same time as case.

Nine of the cases had been employed during one or both of the periods when crocidolite was used, and their controls were chosen to have also worked during these periods. The occupational histories of cases and controls were examined and an assessment made of exposure to crocidolite and also of the level of exposure to chrysotile. There was no indication of whether any individual was a case or control, but many of the mesotheliomas were previously known about in the factory, and the names may have been remembered. Eight of those dying of mesothelioma, and therefore also their controls, started work at the factory before the personnel filing system was set up, and the job histories could be established completely only by individual inquiries, including talking to surviving work-mates. Exposure to crocidolite was classified as definite for working on the crocidolite contract and as fringe for work in the same shed but more than $15 \mathrm{~m}$ from the crocidolite work or for chance intermittent exposure. The results of the study are summarised in table $9 ; 80 \%$ of those dying of mesothelioma had worked on the crocidolite contract compared with only $8 \%$ of the controls. Those with mesothelioma, however, had also been exposed to higher levels of chrysotile than the controls; $90 \%$ had been exposed to more than $5 \mathrm{f} / \mathrm{ml}$ compared with $25 \%$ of the controls. The confounding effect of

Table 9 Exposure to crocidolite of mesotheliomas and controls

\begin{tabular}{|c|c|c|c|c|}
\hline & \multicolumn{4}{|c|}{ Exposure } \\
\hline & Definite & Fringe & None known & Total \\
\hline $\begin{array}{l}\text { Mesotheliomas } \\
\text { Controls }\end{array}$ & $\begin{array}{l}8 \\
3\end{array}$ & $\begin{array}{l}1 \\
7\end{array}$ & $\begin{array}{r}1 \\
30\end{array}$ & $\begin{array}{l}10 \\
40\end{array}$ \\
\hline
\end{tabular}

exposure to chrysotile was eliminated by considering only cases of mesothelioma and their controls who had been exposed to chrysotile at a level of at least 5 $\mathrm{f} / \mathrm{ml}$. This left six cases with 10 controls (table 10). Controls were unevenly distributed among the cases; case $A$ had three eligible controls, $B$ and $E$ two each, and $D, G$, and $J$ only one each. The four cases not shown in table 10 had no eligible controls. Given the pattern of exposure within each set of a case and its controls, the observation that five workers with mesotheliomas had had definite exposure to crocidolite is the most unlikely outcome (probability 1/36 the onesided significance level) in the absence of an association between crocidolite and mesothelioma.

Postmortem material was obtained from seven of the mesotheliomas and an analysis of lung content ${ }^{8}$ carried out (table 11). Case $\mathrm{C}$ had an extremely high value for chrysotile asbestos. There was nothing in the exposure history to explain this; for the last 25 years of his life this man was exposed to an estimated level of 1 to 2 chrysotile fibres $/ \mathrm{ml}$. The crocidolite levels of the five cases with mesotheliomas $(B, C, E$, $\mathrm{G}, \mathrm{H}$ ) with exposure on the crocidolite contract were all high. By contrast, in lungs from consecutive necropsies from six cities and towns in the United Kingdom in 1977 only $8 \%$ exceeded a level of one million fibres of crocidolite per gram. ${ }^{9}$ Thus the lung contents confirm the occupational histories. Mesothelioma $\mathrm{J}$ did not work on the crocidolite contract and his lung content is lower. He did not start work at the factory until he was over 50 and had previously worked in an asbestos cement factory for over 20 years. Therefore his mesothelioma cannot be attributed with any certainty to his exposure in the factory of this study. Case I's job history is not documented, but she may have had fringe exposure to

Table 10 Exposure to crocidolite of mesotheliomas and controls with exposure to chrysotile level of at least $5 \mathrm{f} / \mathrm{ml}$

\begin{tabular}{llllllll}
\hline Reference & $A$ & $B$ & $D$ & $E$ & $G$ & $J$ \\
\hline $\begin{array}{l}\text { Mesotheliomas } \\
\text { Controls }\end{array}$ & + & + & + & + & + & + & - \\
\hline$+=$ Definite exposure to crocidolite. & & &
\end{tabular}


Table 11 Lung contents of mesotheliomas

\begin{tabular}{llc}
\hline Reference & \multicolumn{2}{l}{$\begin{array}{l}\text { Lung contents } \\
\text { (millions fibres/gm) }\end{array}$} \\
\cline { 2 - 3 } & Crocidolite & Chrysotile \\
\hline B & $20 \cdot 1$ & $17 \cdot 2$ \\
C & $39 \cdot 8$ & $616 \cdot 6$ \\
G & $2 \cdot 6$ & $2 \cdot 4$ \\
H & $8 \cdot 3$ & $6 \cdot 2$ \\
I & $14 \cdot 4$ & $17 \cdot 6$ \\
J & $11 \cdot 4$ & $45 \cdot 8$ \\
\hline
\end{tabular}

crocidolite; her lung contents suggest that this may have been considerable.

\section{DOSE-RESPONSE BETWEEN EXPOSURE TO \\ CHRYSOTILE AND LUNG AND}

GASTROINTESTINAL CANCER

A case-control study of deaths due to lung cancer (ICD 162) was carried out. This study was restricted to men since there were few lung cancers in women (table 7). It was also restricted to those who had started work after the personnel files had been set up (to facilitate the establishment of occupational histories), to those who started before the end of 1960 , and to those who survived for at least 10 years after starting work in the factory. There were 106 deaths from lung cancer satisfying these criteria, and three controls were chosen for each case, matched for: (1) year started in factory, (2) date of birth, and (3) survival up to time of death from lung cancer.

For each case the controls were chosen from those satisfying (1) and (3) to give as good a match as possible for date of birth; 97\% of controls were matched within four years. Within the restricted set of men there were 86 who had died of gastrointestinal cancer (ICD 150-159). These men were also included in the study. Further controls were not selected for the deaths from gastrointestinal cancer because these workers had similar distributions of year of birth, year started in factory, and year of death to the lung cancer group (table 12). The gastrointestinal cancers were therefore compared with the controls of the lung cancers, using methods appropriate for unmatched data.

For the two sets of deaths from cancer and the controls, occupational histories were extracted from the files and interpreted in terms of level of chrysotile exposure. Those carrying out this process were given no information on whether or not an individual was a case or a control.

Each occupational history was integrated with respect to time to give the cumulative exposure up to the date of death for the cases, and for controls up to the date of death of the corresponding case of lung cancer. The total duration of exposure was also calcu-
Table 12 Characteristics of deaths from lung cancer, matched controls, and deaths from gastrointestinal cancer

\begin{tabular}{llrl}
\hline & \multicolumn{2}{l}{ No of subjects } & \\
\cline { 2 - 4 } & $\begin{array}{l}\text { Deaths from } \\
\text { lung cancer }\end{array}$ & Controls & $\begin{array}{l}\text { Deaths from } \\
\text { gastrointestinal } \\
\text { cancer }\end{array}$ \\
\hline Year of birth & & & \\
Pre-1899 & 25 & 71 & 19 \\
$19(0)-19$ & 38 & 117 & 29 \\
$1910-19$ & 28 & 82 & 23 \\
$1920-29$ & 13 & 41 & 11 \\
$1930-39$ & 2 & 6 & 4 \\
Total & 106 & 317 & 86
\end{tabular}

Mean year of birth 1907.9

Year started at factory

$1946-50$

$1951-55$

1956-60)

32

41
18

18

Mean vear started $1949 \cdot 6$

Year of death

Pre-1960)

$1961-65$

$1966-70$

$1971-75$

1976-

$1908 \cdot 2$

$1908 \cdot 8$

Mean year died

7
13
24
35
27

$\begin{array}{rr}96 & 17 \\ 122 & 35 \\ 54 & 15 \\ 45 & 19\end{array}$

$1949 \cdot 6 \quad 1950 \cdot 5$

* One control was omitted because it proved impossible to obtain an occupational history.

lated. These two measures were also evaluated up to nine years before the above dates, as done by McDonald et al, ${ }^{10}$ on the basis that recent exposure is irrelevant to the risk of lung cancer. A fifth measure evaluated was the cumulative dose weighted by the time elapsed since the exposure occurred." 1 This measure was evaluated up to the date of death and attaches most importance to the earliest exposure.

The distributions of duration of exposure and cumulative exposure up to death are given in tables 13 and 14. The odds-ratios-that is, the approximate risks of cancer, relative to the lowest exposure group -are also given. For lung cancer there is no indication of an increased risk with either duration of exposure or cumulative exposure. For gastrointestinal cancer there is no sign of an increased risk with cumulative exposure, and although there appears to be a trend with duration of exposure up to 20 years, this trend is not supported by the numbers with more than 20 years' exposure and could have occurred by chance. There was also no sign of increased risk with duration of exposure or with cumulative exposure calculated to nine years before death or with the measure of exposure weighted by elapsed time (tables not shown). Restricting the analysis to cases who survived for at least 15 years after first employment in the factory also did not show any dose-response relationships.

For lung cancer a linear relationship between relative risk and cumulative exposure was fitted using 
Table 13 Distributions of duration of exposure up to death

\begin{tabular}{|c|c|c|c|c|c|}
\hline \multirow{2}{*}{$\begin{array}{l}\text { Duration of } \\
\text { exposure } \\
\text { (years) }\end{array}$} & \multicolumn{3}{|c|}{ No of subjects } & \multicolumn{2}{|c|}{ Odds-ratios } \\
\hline & Controls & $\begin{array}{l}\text { Lung } \\
\text { cancers }\end{array}$ & $\begin{array}{l}\text { Gastrointestinal } \\
\text { cancers }\end{array}$ & $\begin{array}{l}\text { Lung } \\
\text { cancer }\end{array}$ & $\begin{array}{l}\text { Gastrointestinal } \\
\text { cancer }\end{array}$ \\
\hline $\begin{array}{c}0-0.9 \\
1-4.9 \\
5-9.9 \\
10-19.9 \\
20-33 \cdot 5\end{array}$ & $\begin{array}{l}74 \\
86 \\
28 \\
77 \\
52\end{array}$ & $\begin{array}{r}26 \\
29 \\
8 \\
28 \\
15\end{array}$ & $\begin{array}{r}16 \\
24 \\
9 \\
26 \\
11\end{array}$ & $\begin{array}{l}1.00 \\
0.96 \\
0.81 \\
1.03 \\
0.82\end{array}$ & $\begin{array}{l}1.00 \\
1.29 \\
1.49 \\
1.56 \\
0.98\end{array}$ \\
\hline Total & 317 & 106 & 86 & & \\
\hline
\end{tabular}

methods appropriate to matched data. ${ }^{12}$ The coefficient was estimated as 0.00058 per fibre-year $/ \mathrm{ml}$. That is, for a cumulative exposure of 100 fibre-years/ $\mathrm{ml}$ the relative risk was estimated as 1.06 ; the upper $90 \%$ confidence limit was $\mathbf{1 \cdot 8 0}$.

\section{Discussion}

The only evidence of excess mortality associated with asbestos exposure at this factory that we have established is that mesotheliomas have occurred. Of 11 workers dying of mesothelioma in the study, eight worked on the contract in which crocidolite was used and another may have had intermittent exposure to crocidolite. The occupational histories used to obtain this information were supported by data on the lung contents at necropsy, although no control material from deaths due to other causes in this study was found for comparison. One of the two other cases had worked for many years in an asbestos cement factory and, while there was no evidence from inquiries at this factory or from the lung contents at necropsy of exposure to crocidolite, the mesothelioma could not be definitely attributed to his known exposure to chrysotile. The worker who died of a mesothelial tumour in late 1980 had been employed in the factory for only two weeks and, although he is not known to have been exposed to asbestos elsewhere, this is a possibility.

This study, together with a recent study of textile workers exposed only to chrysotile, ${ }^{13}$ confirms that mesotheliomas are rare after exposure only to chrysotile and provide further evidence of the association of this tumour with amphibole asbestos. ${ }^{14}$

There was no evidence of an overall increase in mortality, or of any excess of deaths due to lung cancer either in relation to the national population or, within the factory population, to different levels of exposure. We attempted to obtain information on the smoking habits of men in the lung cancer case-control study, but this information was recorded on so few that it was impossible to allow for smoking in the analysis. Reduced smoking by the workers in the factory, compared with the national population, could possibly have hidden an asbestos effect, but it is unlikely that it would have distorted a dose-exposure relationship within the factory.

There was also no convincing evidence of excess mortality from gastrointestinal tumours either in the main mortality study or in the case-control study.

A noteworthy aspect of our study was the low exposure experienced by the work-force-partly because there were several short-term workers but also a consequence of good environmental control in the factory during the past 30 years. As a result only $5 \%$ of the men employed after 1941 accumulated an exposure of 100 fibre-years $/ \mathrm{ml}$ which, in historical terms, is low.

McDonald et al ${ }^{15}$ in their study of the Quebec chrysotile production industry found a dose-response relationship, but this was determined by large excesses of lung cancer at very high exposures. At 100

Table 14 Distributions of cumulative exposure to death

\begin{tabular}{|c|c|c|c|c|c|}
\hline \multirow{2}{*}{$\begin{array}{l}\text { Cumulative } \\
\text { exposure } \\
(f-y / m l)\end{array}$} & \multicolumn{3}{|c|}{ No of subjects } & \multicolumn{2}{|c|}{ Odds-ratios } \\
\hline & Controls & $\begin{array}{l}\text { Lung } \\
\text { cancers }\end{array}$ & $\begin{array}{l}\text { Gastrointestinal } \\
\text { cancers }\end{array}$ & $\begin{array}{l}\text { Lung } \\
\text { cancer }\end{array}$ & $\begin{array}{l}\text { Gastrointestinal } \\
\text { cancer }\end{array}$ \\
\hline $\begin{array}{c}0-9 \\
10-49 \\
50-99 \\
100-356\end{array}$ & $\begin{array}{r}132 \\
124 \\
40 \\
15\end{array}$ & $\begin{array}{r}50 \\
37 \\
13 \\
5\end{array}$ & $\begin{array}{r}36 \\
40 \\
9 \\
1\end{array}$ & $\begin{array}{l}1 \cdot 00 \\
0 \cdot 79 \\
0 \cdot 86 \\
0 \cdot 88\end{array}$ & $\begin{array}{l}1 \cdot 00 \\
1 \cdot 18 \\
0 \cdot 83 \\
0 \cdot 24\end{array}$ \\
\hline Total & $311^{*}$ & $105^{*}$ & 86 & & \\
\hline
\end{tabular}

*For seven men ( 6 controls, 1 lung cancer) information available on dust levels was insufficient to calculate cumulative exposure. $\mathrm{f}-\mathrm{y} / \mathrm{ml}=$ Fibre-years $/ \mathrm{ml}$. 
fibre-years/ml their estimated SMR for lung cancer was 104 . In our study the corresponding SMR was similar (106) but, whereas the slight excess risk in Quebec was statistically significant, that in our study could have arisen by chance. Peto ${ }^{16}$ gave results from an asbestos textile factory and estimated a risk equivalent to an SMR for lung cancer of about 160 at 100 fibre-years $/ \mathrm{ml}$. This higher value is within the confidence interval of our estimate so the two studies are not necessarily contradictory. Nevertheless, crocidolite as well as chrysotile was processed at the textile factory. Dement et al ${ }^{17}$ reported a study of an asbestos textile factory where only chrysotile was processed. A large excess of lung cancer was observed corresponding to an SMR of 500 at 100 fibre-years $/ \mathrm{ml}$. This finding is in pronounced contrast to any other study where there was exposure only to chrysotile, and the reasons for this have not yet been established. Thomas et al ${ }^{18}$ found no excess deaths due to lung cancer in workers exposed only to chrysotile in an asbestos cement factory. Most of the workers had short periods of exposure and so the cumulative exposures were not high.

The study reported in this paper, together with that at the asbestos cement factory, ${ }^{18}$ show that chrysotile was used in manufacturing industry with no detectable effect on mortality during a period when workers in factories processing amphiboles were experiencing high excess mortality due to lung cancer, mesothelioma, and other cancers.

\section{MLN was supported by a Medical Research Council grant.}

We are grateful to Ferodo Ltd for the opportunity to carry out the study and to all those members of the company who helped, particularly $\mathrm{Mr}$ Bernard Dufficy and Dr Marie Mills. We are also grateful to Dr F Whitwell who supplied necropsy material, Dr F D Pooley who carried out the analyses of lung content, Dr J C Wagner for assessing histological material, and the Office of Population Censuses and Surveys for their collaboration. Finally, we thank Mrs $\mathrm{P}$ Antonis and Miss C Heywood who helped us in the collection and analysis of the data.

\section{References}

' Newhouse ML. Berry G. Skidmore JW. A mortality study of workers manufacturing friction materials with chrysotile asbestos. In: Walton WH, ed. Inhaled Particle V. Oxford: Pergamon, 1982:889-909.

2 Skidmore JW. Dufficy B. Environmental history of a friction material factory. Br J Ind Med 1983;40: 8-12.

${ }^{3}$ Asbestos industry regulations: statutory rules and orders, 1931. No 1140. London: HMSO. 1931.

${ }^{4}$ Asbestos regulations 1969. No 693. London: HMSO. 1969.

5 World Health Organisation. International classification of diseases, manual of the international statistical classification of diseases. injuries, and causes of death. 8th rev. Geneva: WHO. 1967.

${ }^{6}$ Case RAM. Lea AJ. Mustard gas poisoning. chronic bronchitis. and lung cancer. Br J Prev Soc Med 1955:9:62-72.

${ }^{7}$ Liddell FDK. McDonald JC. Thomas DC. Methods of cohort analysis: appraisal by application to asbestos mining. Journal of the Royal Statistical Society A 1977:140:469-91.

${ }^{8}$ Pooley FD. Clark NJ. Quantitative assessment of inorganic fibrous particulates in dust samples with an analytical transmission electron microscope. Ann Occup Hyg 1979:22:253-71.

9 Wagner JC. Pooley FD. Berry G, et al. A pathological and mineralogical study of asbestos-related deaths in the United Kingdom in 1977. In: Walton WH. ed. Inhaled Particles V. Oxford: Pergamon, 1982.

${ }^{10}$ McDonald JC. Liddell FDK. Gibbs GW. Eyssen GE. McDonald AD. Dust exposure and mortality in chrysotile mining. 1910-75. Br J Ind Med 198();37:11-24.

" Jahr J. Dose-response basis for setting a quartz threshold limit value. A new simple formula for calculating the "lifetime dose" of quartz. Arch Environ Health 1974:29:338-40.

12 Berry G. Dose-response in case-control studies. J Epidemiol Community Health 1980;34:217-22.

${ }_{13}$ McDonald AD. Fry JS. Mesothelioma and fibre type in three American asbestos factories-preliminary report. Scand J Work Environ Health 1982;8,suppl 1:53-8.

14 Acheson ED. Bennett C. Gardner MJ. Winter PD. Mesothelioma in a factory using amosite and chrysotile asbestos. Lancet 1981: ii: $1403-6$.

15 McDonald JC. Gibbs GW. Liddell FDK. Chrysotile fibre concentration and lung cancer mortality: a preliminary report. In: Wagner JC, ed. Biological effects of mineral fibres. Lyon: International Agency for Research into Cancer. 1980: 811-7. (Scientific publication No 30.)

16 Peto J. Lung cancer mortality in relation to measured dust levels in an asbestos textile factory. In: Wagner JC, ed. Biological effects of mineral fibres. Lyon: International Agency for Research into Cancer, 1980:829-36. (Scientific publication No 30.)

${ }^{17}$ Dement JM. Harris RL. Symons MJ. Shy C. Estimates of doseresponse for respiratory cancer among chrysotile asbestos textile workers. In: Walton WH, ed. Inhaled Particles $V$. Oxford: Pergamon Press, 1982.

18 Thomas HF. Benjamin IT. Elwood PC. Sweetnam PM. A further follow-up study of workers from an asbestos cement factory. $\mathrm{Br}$ J Ind Med 1982:39:273-6. 